\title{
Nutritional programming: prenatal nutritional effects on the regulation of growth and metabolism
}

\author{
C.C. Metges ${ }^{1}$ and H.M. Hammon \\ Research Institute for the Biology of Farm Animals (FBN), \\ Research Unit Nutritional Physiology ,Oskar Kellner" \\ Wilhelm-Stahl-Allee 2, 18196 Dummerstorf, Germany
}

\begin{abstract}
Research on the foetal nutritional origins of adult onset disease in rodents have uncovered a plethora of programming effects on adult metabolic and cardiovascular health. This relationship is a consequence of disordered foetal growth and alteration of the programmed development of various homeostatic control points. Until recently, applicability of early nutritional programming to livestock species has received little attention. An overview is given on the evidence of foetal programming effects brought about by global and protein under- and overnutrition in rodents and sheep. Maternal and foetal endocrine alterations of glucocorticoids, insulin and the insulin-like growth factor system related to maternal malnutrition during pregnancy are discussed.
\end{abstract}

KEY WORDS: foetus, undernutrition, glucocorticoids, maternal low protein, maternal high protein, pregnancy diet, programming

\section{INTRODUCTION}

Foetal growth is controlled by the interaction of the genome and the availability of essential substrates (glucose and amino acids). Maternal adaptation to pregnancy involves redirection of oxygen and nutrients to the gravid uterus, and subsequent placental delivery to the foetus. This modulation occurs directly, as well as indirectly via endocrine mechanisms. The placenta and its capacity to transfer substrates, to utilize and modify these substrates integrates foetal and placental metabolism through a number of substrate exchanges.

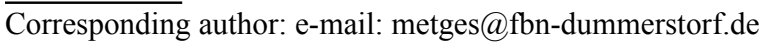


The concept that maternal nutritional imbalances or under- and overnutrition, and thus an inadequate nutritional environment for the developmental stage of the foetus could program gene expression for life and predispose the individual to a range of adult metabolic and cardiovascular disorders has been proposed on the basis of a series of epidemiological human studies. Considering the evidence led Hales and Barker (1992) to formulate the 'thrifty phenotype' hypothesis, which implies that individuals who survived nutrient deficits during early life are likely to experience health disorders in adult life when they consume a postnatal diet adequate in nutrients and energy, and especially when they have access to hypercaloric or highly palatable diets. In many populations worldwide epidemiological evidence relates low birth weight to increased risk for syndrome $\mathrm{X}$, insulin resistance, coronary heart disease, and high blood pressure in adult age (Hales and Barker, 1992; Barker et al., 1993; Law and Shiell, 1996; Hofman et al., 1997; Eriksson et al., 1999; Godfrey and Barker, 2000; Mi et al., 2000). This relationship is a consequence of disordered foetal growth and alteration of the programmed development of various homeostatic control points. Recent research on the foetal nutritional origins of adult onset disease in rodents have uncovered a whole plethora of programming effects on adult metabolic and cardiovascular health including low birth weights due to a maternal deficiency in protein or energy.

Until recently, applicability of early nutritional programming to livestock species has received little attention. So far efforts to manipulate maternal nutritional status centred on short periods before mating because a moderately high level of nutrition results in a maximized rate of ovulation. Since the 1970's it is also known that litter size and birth weight of pigs are relatively insusceptible to varied levels of maternal dietary protein intakes during gestation (Mahan and Mangan, 1975; Gatford et al., 2004) but it is uncertain whether gestational protein levels below or above sows' requirements have effects on performance traits later in life. In this context it is of interest that lower birth weight piglets $(<1.2 \mathrm{~kg})$ from otherwise normal litters have later on lower daily gains, higher body fat contents, lower muscle mass and higher drip losses (Kuhn et al., 2003). Up to now systemic studies in farm animals of long-term effects of early life nutrition on adult performances, such as growth rates, body composition, meat quality, immune status or stress resistance are scarce. If future studies indicate that phenotypes caused by foetal (i.e. maternal) malnutrition as described in the rodent model are equally relevant in farm animal species early nutritional programming could represent the next frontier in animal science as earlier pointed out by Cronjé (2003).

The purpose of this article is to give an overview on the available evidence of foetal programming effects brought about by maternal global or protein under- and overnutrition in rodents and sheep, two species for which a relatively large body of 
evidence does exist. Maternal and foetal endocrine alterations of glucocorticoids, insulin and insulin-like growth factors (IGF) related to maternal malnutrition during pregnancy are discussed as mediators of foetal growth retardation and programming of later impaired performance or health disorders.

\section{FOETAL AND POSTNATAL CONSEQUENCES OF MATERNAL MALNU- TRITION}

\section{Energy or global undernutrition and overnutrition}

Studies in rodents show that various degrees of maternal global undernutrition during gestation lead to development of an adult offspring phenotyp similar to syndrome $\mathrm{X}$ in humans. A food intake levels of $30 \%$ of an ad libitum diet throughout gestation in rats resulted in foetal growth retardation reflected by decreased offspring body weight at birth (Vickers et al., 2000). At weaning offspring was assigned to either a control or a hypercaloric diet. At 125 days of age offspring of undernourished (UN) mothers were shorter in body length but had larger retroperitoneal fat pads. Systolic blood pressure in offspring of UN mothers was elevated and increased further with the hypercaloric diet. In addition, these animals were hyperinsulinemic and had higher fasting leptin concentrations (Vickers et al., 2000). Other rat studies have also shown that maternal malnutrition during pregnancy results in adult adiposity in the offspring (Anguita et al., 1993; Jones et al., 1995). In rats, not only adiposity but also behavioural aspects may have a prenatal origin. Vickers et al. $(2000,2003)$ reported that offspring of undernourished rat dams was less active (voluntary locomotor activity) and hyperphagic at adult age.

In sheep, a 50\% maternal undernutrition (UN) during the last 30 days of pregnancy (days 115-145), i.e. the period of rapid foetal growth, caused no difference in foetal body mass or placental weights at days 144-145 between the UN and control groups (Edwards and McMillen, 2001). However, foetal plasma glucose and insulin concentration were lower (Edwards and McMillen, 2001; Yuen et al., 2002), and arterial blood pressure at days 115-125 of gestation was higher in UN foetuses. Although no difference between foetal plasma cortisol concentrations was found between the two groups, combining $\mathrm{UN}$ and control groups a positive correlation between foetal plasma cortisol and arterial blood pressure became evident (Edwards and McMillen, 2001). A $40 \%$ maternal undernutrition during the main period of placental growth (days 28 to 80 of gestation) in ewes and then either fed to appetite or corresponding to requirements resulted in higher foetal adipose tissue mass at day 140 while no difference in foetal weight was observed indicating a programming effect 
on adiposity independent of any effect on birth weight (Bispham et al., 2003). Adipose tissue of UN foetuses between 28 and 80 days gestation had an increased IGF type-1- and IGF type-2-receptor mRNA abundance which has an anabolic effect on foetal adipose tissue and appears to explain higher fat deposition in the UN foetuses.

With periconceptual undernutrition in ewes (60 days before mating until 30 days after) followed by maintenance level feeding thereafter, foetal plasma cortisol concentrations at days 127-128 were higher in UN foetuses while maternal cortisol did not differ between groups at this time (Bloomfield et al., 2003). Also, like in other studies of prenatal undernutrition foetal weight between groups did not differ. However, in another study chest girth increment was reduced in UN foetuses until delivery, indicating that periconceptional undernutrition alters growth trajectory (Oliver et al., 2005).

Intuitively, one relates foetal growth retardation with maternal undernutrition. However, overnourishing adolescent sheep throughout pregnancy results in restriction of placental mass by about $45 \%$ in late pregnancy, which leads to a significant reduction of birth weight relative to adolescent dams receiving a moderate nutrient intake (Wallace et al., 1997). Placental and foetal growth restriction was associated to reduced uterine and umbilical blood flows, resulting in hypoxic and hypoglycemic foetuses (Wallace et al., 2004). However, placental glucose transport capacity was not different between the overnourished and the control ewes when expressed on a placental weight-specific basis, indicating that the small size of the placenta per se is the major limitation to placental glucose transfer (Wallace et al., 2002). In contrast, increased nutrient intake during the second half of gestation in adult ewes resulted in greater foetal body mass but less perirenal adipose tissue at day 140 of gestation in the well-fed dams as compared to the control (Budge et al., 2000).

\section{Protein undernutrition and protein excess}

A widely established model to study foetal programming by maternal malnutrition and exploring mechanisms responsible for the development of adult degenerative disease is the maternal low protein (MLP) model in rodents. Usually an isocaloric casein-based semi-synthetic diet of about $40-50 \%$ protein restriction during pregnancy is compared with an adequate maternal diet of 180$200 \mathrm{~g}$ protein $/ \mathrm{kg}$ diet.

In many studies it has been shown that a low protein intake throughout pregnancy in rats and mice results in foetal growth retardation, selective organ growth, and accelerated catch-up growth (Desai et al., 1997; Petrie et al., 2002). El-Khattabi et al. (2003) reported reduced foetal liver weight and IGF-1 levels in plasma whereas the abundance of IGFBP1 and IGFBP2 was augmented. Even 
a low protein diet during the last week of pregnancy only led to an impaired pancreatic beta cell mass (Bertin et al., 1999). In adult offspring increased hepatic glucose output, age-related loss of glucose tolerance, hyperinsulinaemia, insulin resistance, altered brain development and hypertension was observed (Ozanne et al., 1996, 2001, 2003; Gardner et al., 1997; Bennis-Taleb, 1999; Fernandez-Twinn et al., 2005). Langley et al. (1994) demonstrated that low protein intake during pregnancy compromises the immune system in the young adult offspring.

There are only few studies in which postnatal body mass gain and body fat mass was investigated in offspring born to mothers fed low protein diets during pregnancy. Ozanne et al. (2004), recently reported in mice that this phenotype was characterized, although small at birth, by increased catch-up growth during lactation and post-weaning and higher body weight at 10 weeks of age.

Not only protein malnutrition results in low birth weight in rats. We have shown that also maternal isocaloric high protein diet during pregnancy was followed by a reduction of body weight at day of life 2 (Figure 1) but a higher body weight than controls at weaning and up to week 6 in the offspring (Metges, 2001; Daenzer et al., 2002). Incidentally, in women high protein intake during pregnancy was also associated to low birth weight (Sloan et al., 2001). Exposure to high protein diets during pregnancy plus lactation resulted in a moderately decreased body weight of pups until weaning as compared to maternal low protein diet (Gambardella et al., 1987; Daenzer et al., 2002; Daenzer, 2003). Furthermore, the offspring from maternal high protein feeding had a reduced total energy expenditure and a higher body fatness at week 9 (Daenzer et al., 2002). In contrast, postnatal protein overnutrition only did not lead to an obese phenotype (Daenzer et al., 2002). This suggests that upon prenatal high protein exposure offspring overcompensated in terms of catch-up growth which was followed by increased body fat in young adults which provides first evidence that in utero high protein exposure can predispose offspring to adult adiposity.
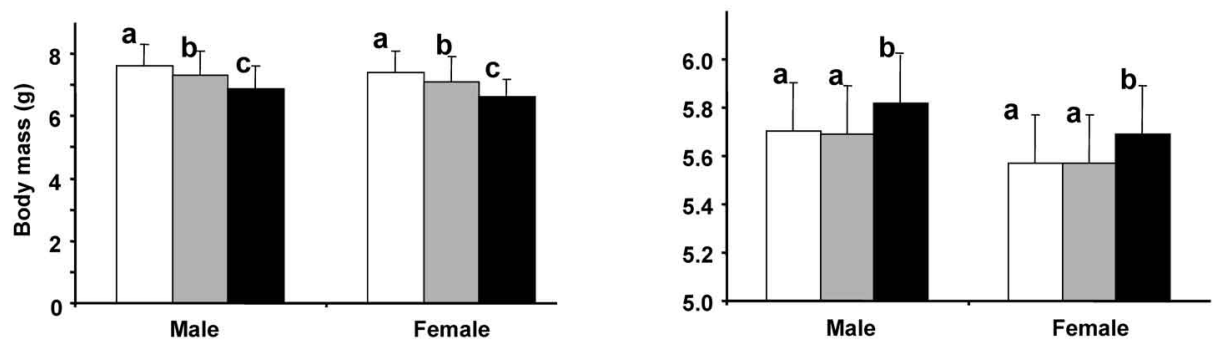

Figure 1. Body mass and body length of rat offspring at age day 2. Pregnant mothers were fed either isoenergetic low protein (11\%; black bars), high protein (39\%; grey bars), and control diets (20\% protein; empty bars). $\mathrm{P}<0.05$ (Daenzer, 2003) 


\section{MECHANISMS OF NUTRITIONAL PROGRAMMING}

Generally, foetal growth can be divided in three main periods: early embryo growth until implantation, placental growth, and foetal growth. In the sheep, as in most other mammals, the major phase of placental growth occurs during the first half of pregnancy, while the foetus accumulates more than three quarters of its eventual mass during the final trimester of gestation. Absolute placental and foetal, and thus maternal nutrient requirements are at a maximum in late pregnancy. Effects of maternal nutrition, i.e. prenatal nutritional imbalance can be exerted at many stages of development, from prior to conception until after birth and may be expressed at the time of the nutritional insult or much later.

The signals by which maternal nutrition affects the offspring must be related to maternal nutritional state and must have the capacity to reach the embryo/ foetus, to be 'read' by it and to modify expression of selected genes. Maternal hormones such as insulin, IGFs, growth hormone and thyroid hormones do not cross the placenta in physiologically important quantities (Brown and Thorburn, 1989) but may indirectly regulate nutrient partitioning between the maternal, placental and foetal compartments. Maternally derived endocrine regulators of nutrient partitioning may operate via secondary changes in maternal or placental metabolism, utero-placental blood flow or nutrient transport functions. The size and nutrient transfer capacity of the placenta play a central role in determining the prenatal growth trajectory of the foetus and hence directly influences its birth weight and postnatal viability (Schneider, 1996; Bell et al., 1999). Placental hormones such as progesterone, oestrogen and placental lactogen are mainly secreted in the maternal circulation in order to alter maternal physiology to benefit the growing foetus (Anthony et al., 1995).

During foetal life the ovine adrenal gland has three phases of activity. Early in gestation it is capable of secreting cortisol but then goes through a quiescent stage between about 90 and 120 days (Glickman and Challis, 1980). After this period there is a gradual increase in cortisol production. Periconceptual (days -60 to +30 ), mid (days 28 to 80 ), and late gestation undernutrition (days 115 to 145 ) in sheep leads to different maternal plasma cortisol levels which may be related to differences in foetal nutrient demands in the course of gestation (Edwards and McMillen, 2001; Bispham et al., 2003; Bloomfield et al., 2004). In all species studied there is a surge in circulating foetal cortisol concentration before birth. This cortisol increase is critical for the maturation of many organs in preparation for extrauterine life such as the growth and development of the lung, the brain, skeletal muscle and the kidneys (Meyer, 1985). In sheep and in pigs the cortisol surge is essential for the initiation of normal parturition, and activation of the foetal hypothalamic-pituitary-adrenal (HPA) axis is a central mechanism by which the foetal influence on gestation length is exerted (Kattesh et al., 1997; 
Challis et al., 2000). It was found that in late gestation foetal plasma cortisol of ewes undernourished during periconceptual period increased earlier which was followed in many cases by preterm delivery (Bloomfield et al., 2003). In contrast, a $50 \%$ reduction in maternal nutrient intake during the last 30 days of gestation when foetal nutrient demands are highest, does not alter foetal plasma cortisol concentration until the end of pregnancy as compared to control (Edwards and McMillen, 2001).

The placenta modulates the exposure of the foetus to maternal glucocorticoids and prevents an excess of glucocorticoids in the foetal circulation by an enzyme regulating the biological activity of glucocorticoids. This enzyme, which is present also in other tissues, occurs in two isoforms: 11ß-hydroxysteroiddehydrogenase (HSD)1 (11ß-HSD1) and 11ß-HSD2 (Bertram et al., 2001; Whorwood et al., 2001; Klemcke et al., 2003). The 11ß-HSD2 inactivates cortisol to cortison while 11ß-HSD1 catalyzing the conversion of cortisone to bioactive cortisol (Figure 2). Consequently, the downregulation of 11ß-HSD2, an upregulation of 11ß-HSD1 or an upregulation of glucocorticoid receptor would lead to an overexposure of the foetus to cortisol. Untimely high levels of cortisol in foetal plasma therefore reduce foetal growth or cause disproportionate growth as shown in rats (Lesage et al., 2001). In the porcine foetus plasma cortisol and foetal weight on days 65 and 100 of gestation was inversely related (Ashworth et al., 2001). Further, in pigs an inverse relation between foetal plasma cortisol and birth weight was shown (Wise et al., 1991).

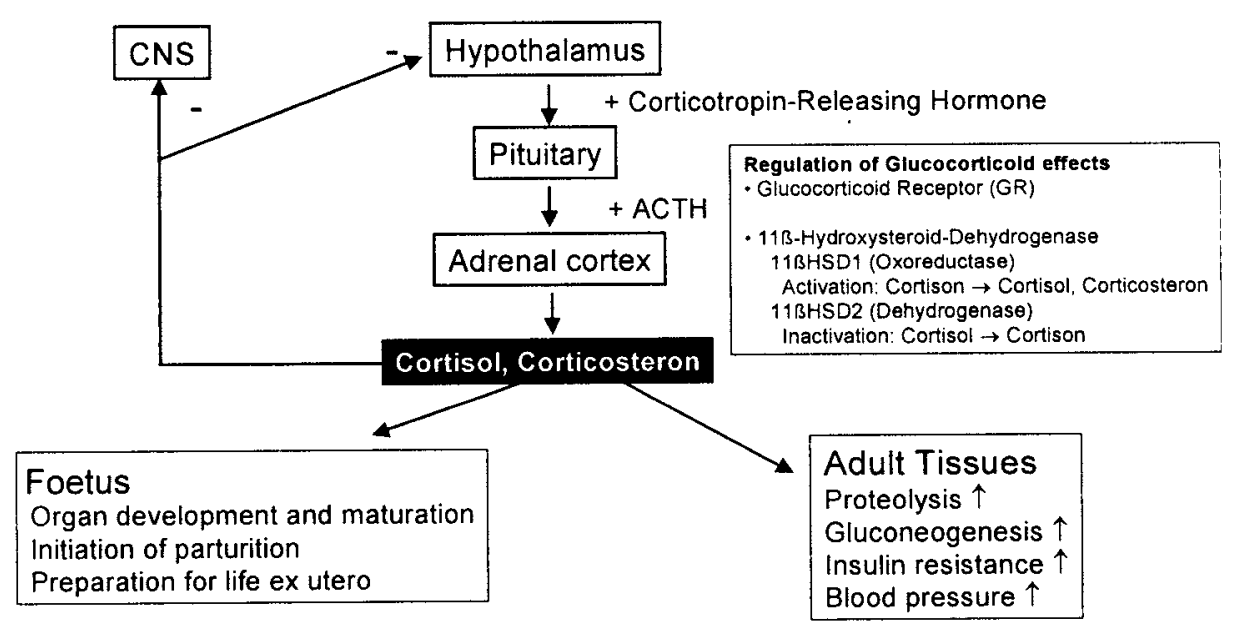

Figure 2. Hypothalamic-pituitary-adrenal (HPA) axis: schematic representation of the regulation of glucocorticoid effects 
Bertram et al. (2001) demonstrated in rat dams fed low protein diet throughout gestation that placental 11ß-HSD2 mRNA expression was reduced which leads to an overexposure to maternal cortisol. In subsequent postnatal life of rat progeny 11ß-HSD2 mRNA was also reduced while glucocortiocoid receptor mRNA and protein was increased indicating an enhanced glucocorticoid effect.

Maternal undernutrition during early to midgestation increased glucocorticoid receptor mRNA in adrenal, kidney, liver, and perirenal adipose tissue of neonatal sheep. In parallel, there was higher expression of 11ß-HSD1 while 11ß-HSD2 in adrenals and kidneys was decreased (Whorwood et al., 2001). Furthermore, the maternal low protein induced hypertension in rat offspring can be prevented by pharmacological blockade of maternal corticosterone synthesis, an effect that is reversed by maternal corticosterone replacement (Langley-Evans, 1997). These findings indicate that the HPA axis plays a key role in foetal growth programming, and is regulated by nutrient availability.

There is evidence from various species that one of the dominant foetal endocrine influences of foetal growth is the IGF system. Deletion of IGF-1 and IGF-2 genes in mice results in severe growth retardation due to muscle dystrophy or postnatal lethality in most animals (Liu et al., 1993; Lopez et al., 1999). Conversely, over-expression of IGF-1 during intrauterine development leads to an increased muscle mass and myofibre hypertrophy, even when over-expression is confined specifically to muscle (Mathews et al., 1988; Coleman et al., 1995). Bioactivity and availability of IGFs are modulated by specific binding proteins (IGFBP) of which currently six are characterized (Clemmons, 1998). In contrast to postnatal life, in utero the predominant IGFBPs are IGFBP1 and IGFBP2 whereas IGFBP3 is low. Determinants of foetal IGF-1 and IGFBP levels are nutrient availability (Bassett et al., 1990; Oliver et al., 1993) and hormones such as insulin and glucocorticoids (Li et al., 1993; Rivero et al., 1995; Li et al., 2002). In contrast, growth hormone $(\mathrm{GH})$ appears to have little effect on foetal plasma IGF-1 levels or intrauterine growth despite high GH levels in utero (Gluckman et al., 1979; Fowden, 1995).

Maternal undernutrition leads to a decline in foetal IGF-1 levels, which are restored by glucose or insulin but not by amino acid infusion (Oliver et al., 1993). Restricting maternal dietary intake early in pregnancy has also been shown to lower IGF-1 gene expression in foetal ovine skeletal muscle near term (Brameld et al., 2000). Also in rats a maternal low protein diet leads to reduced IGF-1 levels in foetal plasma (El-Khattabi et al., 2003). These effects of nutrient availability may be due to changes in the foetal insulin level (Fowden, 1995). It has been earlier shown by foetal pancreatomy, which leads to reduced foetal IGF-1 levels and growth, that foetal insulin release seems to modulate foetal IGF-1 levels (Gluckman et al., 1987). These conclusions are supported by findings showing that insulin deficiency in the foetus is associated with lower growth (Menon and 
Sperling, 1996). In contrast, in mild gestational diabetes the foetus has to deal with an increased glucose supply and adaptations occur in foetal insulin production leading to increased anabolism involving the uptake of glucose and amino acids and eventually foetal macrosomia. An extreme excess of glucose in the foetal circulation due to severe diabetes in pregnant rats results in B-cell overstimulation and low foetal insulin levels followed by microsomia (Aerts and Van Assche, 2003). Overnutrition in pregnant adolescent sheep also leads to high maternal plasma insulin and IGF-1 levels. However, this ensures the anabolic drive to maternal tissue synthesis at the expense of placental growth and thus results in limited foetal growth due to a restriction of placental transport capacity (Wallace et al., 1997). Interestingly, in rat offspring with foetal growth retardation caused by maternal low protein diet or undernutrition IGF-1 therapy promotes postnatal catch-up growth, and alleviates obesity, hyperinsulinaemia, hyperleptinaemia, and hypertension, respectively (Muaka et al., 1997; Vickers et al., 2001).

Maternal undernutrition increases foetal IGFBP-1 and IGFBP-2 while IGFBP-3 concentration is decreased (Gallaher et al., 1992, 1994). Similar results have been reported by El-Khattabi et al. (2003) with maternal low protein diet suggesting a modulation of IGF-1 biologic activity by IGF binding proteins.

Glucocorticoids have a profound influence on foetal skeletal muscle IGF-1 mRNA expression in late gestation of sheep. The ontogenic increase of plasma cortisol concentration in foetal sheep between days 110-145 of pregnancy paralleled the prepartum decline in muscle IGF-1 mRNA abundance ( $\mathrm{Li}$ et al., 2002). In contrast foetal adrenalectomy prevented the prepartum rise of plasma cortisol and abolished the decline in muscle IGF-1 mRNA abundance ( $\mathrm{Li}$ et al., 2002). As shown in Table 1, a cortisol infusion for 5 days in intact and adrenalectomized foetus increases plasma cortisol about 6-fold, and decreases IGF-1 mRNA abundance in foetal skeletal muscle (Li et al., 2002). Cortisol, therefore, appears to downregulate IGF-1 gene expression in ovine skeletal muscle during late foetal development.

Table 1. Skeletal muscle IGF-1 mRNA expression in intact and adrenalectomized foetal sheep after 5 days infusion with cortisol or saline (modified after Li et al., 2002)

\begin{tabular}{lccc}
\hline Item & Gestational age, days & Saline infusion & Cortisol infusion \\
\hline Adrenalectomy & $128-131$ & $9.5 \pm 1.0^{\mathrm{a}}$ & $2.1 \pm 1.1^{\mathrm{b}}$ \\
Intact & $110-114$ & $8.7 \pm 0.8^{\mathrm{a}}$ & $3.6 \pm 1.1^{\mathrm{b}}$ \\
Intact & $127-130$ & $7.6 \pm 0.5^{\mathrm{a}}$ & $1.4 \pm 0.4^{\mathrm{b}}$ \\
\hline
\end{tabular}

a,b significantly different at $\mathrm{P}<0.05$

Since skeletal muscle accounts for 25 to $35 \%$ of foetal body weight during late gestation, downregulation of local IGF-1 expression earlier in gestation is likely to have effects not only on muscle development but also for overall foetal growth. 
IGF-1 infusion studies show that the mode of action might be reduction of foetal protein breakdown, enhanced foetal substrate uptake and increased placental uptake of amino acids from the mother (Harding et al., 1994). Administration of IGF-1 in pregnant rats in late gestation (days 18 to 21) promotes placental amino acid supply (leucine, isoleucine, tryptophan, phenylalanine, tyrosine) from mother to foetuses and enhances foetal growth (Thongsong et al., 2002).

In addition to alterations of glucocorticoids, insulin and IGF-1, maternal under- or overnutrition during gestation also was reported to result in changes of other maternal hormone levels such as progesterone, oestrogen, prolactin, thyroid hormones, growth hormone and leptin (Wallace et al., 1997, 2003; Ashworth et al., 2000; Budge et al., 2000; Thomas et al., 2001; Bispham et al., 2003; Fernandez-Twinn et al., 2003; Bloomfield et al., 2004). Whether glucocorticoids are primarily triggered by foetal nutrient surplus or shortage and act as master regulator orchestrating other endocrine systems is unclear. The importance of these hormones for nutrient partitioning between mother and foetus, foetal growth, and the programming of postnatal growth, and the potential interrelationships is not yet fully understood, and beyond the scope of this short review.

\section{CONCLUSIONS}

It has become evident that the maternal milieu in a growth restricted pregnancy is altered in many ways. Foetal growth retardation, high blood pressure, and adiposity can be programmed in utero by maternal protein or energy overnutrition as well as undernutrition. The precise mechanisms that relate prenatal nutritional environment to later dysregulation of growth and metabolism are not completely understood. It remains to be determined whether these are related to alterations of gene transcription, mRNA stability or nucleocytoplasmic mRNA transport. Under conditions of in utero nutrient restriction or possibly excess, the foetus responds, in the short-term, by making suitable adaptations to accommodate the disturbance in substrate supply. The long-term postnatal outcome of these adaptations is represented as a relative propensity toward a reduced performance or a diseased state. The nutritional insult does not need to last throughout pregnancy and foetal adaptations to nutrient deficiency or excess are dependent on the stage of gestation (embryo development, maximum placenta growth, rapid foetal growth), the duration and the severity of the insult, and long-term outcomes can vary. Available evidence suggest that the maternal and/or foetal endocrine systems facilitate such adaptations with the placenta mediating the cross-talk between mother and foetus and acting as a nutrient sensor. A key influence underlying the reprogramming of the foetal hypothalamic-pituitary-adrenal axis, appears to be the exposure of the foetus to excess glucocorticoids derived from maternal circulation (Bertram et al., 
2001), or alternatively, a suppression of the maternal HPA axis (Bloomfield et al., 2004). Glucocorticoid hormones are essential mediators of the somatotrophic axis, which regulate nutrient partitioning between the maternal, placental and foetal compartments, and subsequently foetal growth.

In many nutritional programming studies in rodent and sheep models the degree of maternal under- or overfeeding during gestation is rather severe. It remains to be determined whether a more subtly altered nutrient composition or energy content above or below the recommended intake levels is relevant for foetal nutritional programming and has long-term consequences for health and performance traits in farm animals.

\section{REFERENCES}

Aerts L., Van Assche F.A., 2003. Intra-uterine transmission of disease. Placenta 24, 905-911

Anguita R.M., Sigulem D.M., Sawaya A.L., 1993. Intrauterine food restricition is associated with obesity in young rats. J. Nutr. 123, 1421-1428

Anthony R.V., Pratt S.L., Liang R., Holland M.D., 1995. Placental-fetal hormone interactions: impact on fetal growth. J. Anim. Sci. 73, 1861-1871

Ashworth C.J., Finch A.M., Page K.R., Nwagwu M.O., McArdle H.J., 2001. Causes and consequences of fetal growth retardation in pigs. Reproduction, Suppl. 58, 233-246

Ashworth C.J., Hoggard N., Thomas L., Mercer J.G., Wallace J.M., Lea R.G., 2000. Placental leptin. Rev. Reprod. 5, 18-24

Barker D.J.P., Gluckman P.D., Godfrey K.M., Harding J.E., Owens J.A., Robinson J.S., 1993. Fetal nutrition and cardiovascular disease in adult life. Lancet 341, 938-941

Bassett N.S., Oliver M.H., Breier B.H., Gluckman P.D., 1990. The effect of starvation on plasma insulinlike growth factor I concentrations in the late gestation ovine fetus. Pediat. Res. 27, 401-404

Bell A.W., Hay W.W., Erhardt R.A., 1999. Placental transport of nutrients and its implications for fetal growth. J. Reprod. Fertil., Suppl. 54, 401-410

Bennis-Taleb N., Remacle C., Hoet J.J, Reusens B., 1999. A low-protein isocaloric diet during gestation affects brain development and alters permanently cerebral cortex blood vessels in rat offspring. J. Nutr. 129, 1613-1619

Bertin E., Gangnerau M.N., Bailbe D., Portha B., 1999. Glucose metabolism and beta-cell mass in adult offspring of rats protein and/or energy restricted during the last week of pregnancy. Amer. J. Physiol. 277, Pt. 1, E11-E17

Bertram C., Trowern A.R., Copin N., Jackson A.A., Whorwood C.B., 2001. The maternal diet during pregnancy programs altered expression of the glucocorticoid receptor and type 211 betahydroxysteroid dehydrogenase: potential molecular mechanisms underlying the programming of hypertension in utero. Endocrinology 142, 2841-2853

Bispham J., Gopalakrishnan G.S., Dandrea J., Wilson V., Budge H., Kreisler D.H., Broughton Pipkin F., Stephenson T., Symonds M.E.S., 2003. Maternal endocrine adaptation throughout pregnancy to nutritional manipulation: consequences for maternal plasma leptin and cortisol and the programming of fetal adipose tissue development. Endocrinology 144, 3575-3585

Bloomfield F.H., Oliver M.H., Hawkins P., Campbell M., Phillips D.J., Gluckman P.D., Challis J. R.G., Harding J. E., 2003. A periconceptual nutritional origin for noninfectous preterm birth. Science 300,606 
Bloomfield F.H., Oliver M.H., Hawkins P., Holloway A., Campbell M., Gluckman P.D., Harding J.E., Challis J.R.G., 2004. Periconceptual undernutrition in sheep accelerates maturation of the fetal hypothalamic-pituitary-adrenal axis in late gestation. Endocrinology 145, 4278-4285

Brameld J.M., Mostyn A., Dandrea J., Stephenson T.J., Dawson J.M., Buttery P.J., Symonds M. E., 2000. Maternal nutrition alters the expression of insulin-like growth factors in fetal sheep liver and skeletal muscle. J. Endocrinol. 167, 429-437

Brown C.A., Thorburn G.D., 1989. Endocrine control of fetal growth. Biol. Neonate 55, 331-346

Budge H., Bispham J., Dandrea J., Evans E., Heasman L., Ingleton P.M., Sullivan C., Wilson V., Stephenson T., Symonds M.E., 2000. Effect of maternal nutrition on brown adipose tissue and its prolactin receptor status in the fetal lamb. Pediat. Res. 47, 781-786

Challis J.R.G., Matthews S.G., Gibbs W., Lye S.J., 2000. Endocrine and paracrine regulation of birth at term and preterm. Endocrine Rev. 21, 514-550

Clemmons D.R., 1998. Role of insulin-like growth factor binding proteins in controlling IGF actions. Mol. Cell Endocrinol. 140, 19-24

Coleman M.E., DeMayo F., Yin K.C., Lee H.M., Geske R., Montgomery C., Schwartz R.J., 1995. Myogenic vector expression of insulin-like growth factor-I stimulated muscle cell differentiation and myofiber hypertrophy in transgenic mice. J. Biol. Chem. 270, 12109-12116

Cronjé P.B., 2003. Implications of nutritional programming of gene expression during early development for livestock production. In: L.'t Mannetje, L. Ramírez-Avilés, C.A. SandovalCastro, J.C. Ku-Vera (Editors). Matching Herbivore Nutrition to Ecosystems Biodiversity. Proceedings of the $6^{\text {th }}$ International Symposium - Nutrition Herbivores. Yucatan (Mexico), pp. 321-332

Daenzer M., 2003. Einfluss hoher Nahrungszufuhr auf die prä- und postnatale Entwicklung sowie Parameter des Energiestoffwechsels. PhD. Thesis, Mathematisch-Naturwissenschaftliche Fakultät, Universität Potsdam

Daenzer M., Ortmann S., Klaus S., Metges C.C., 2002. Prenatal high protein exposure decreases energy expenditure and increases adiposity in young rats. J. Nutr. 132, 142-144

Desai M., Byrne C.D., Meeran K., Martenz N.D., Bloom S.R., Hales C.N., 1997. Regulation of hepatic enzymes and insulin levels in offspring of rat dams fed a reduced-protein diet. Amer. J. Physiol. 273, G899-G904

Edwards L.J., McMillen I.C., 2001. Maternal undernutrition increases arterial blood pressure in the sheep fetus during late gestation. J. Physiol. 533.2, 561-570

El-Khattabi I., Gregoire F., Remacle C., Reusens B., 2003. Isocaloric maternal low-protein diet alters IGF-I, IGFBPs, and hepatocyte proliferation in the fetal rat. Amer. J. Physiol.-Endocrinol. Met. 285, E991-E1000

Eriksson J.G., Forsen T., Tuomilehto J., Winter P.D., Osmond C., Barker D.J., 1999. Catch-up growth in childhood and death from coronary heart disease: longitudinal study. BMJ 318, 427-431

Fernandez-Twinn D.S., Ozanne S.E., Ekizoglou S., Doherty C., James L., Gusterson B., Hales C.N., 2003. The maternal endocrine environment in the low-protein model of intra-uterine growth restriction. Brit. J. Nutr. 90, 815-822

Fernandez-Twinn D.S., Wayman A., Ekizoglou S., Martin M.S., Hales C.N., Ozanne S.E., 2005. Maternal protein restriction leads to hyperinsulinemia and reduced insulin-signaling protein expression in 21-mo-old female rat offspring. Amer. J. Physiol.-Regul. Integr. C. 288, R368-R373

Fowden A.L., 1995. Endocrine regulation of fetal growth. Reprod. Fert. Develop. 7, 351-363

Gallaher B.W., Breier B.H., Oliver M.H., Harding J.E., Gluckman P.D., 1992. Ontogenic differences in the nutrtitional regulation of circulating IGF binding proteins in sheep plasma. Acta Endocrinol. $126,49-54$ 
Gallaher B.W., Oliver M.H., Eichhorn K., Kessler U., Kiess W., Harding J.E., Gluckman P.D., Breier B.H., 1994. Circulating insulin-like growth factor II/mannose-6-phosphate receptor and insulinlike growth factor binding proteins in fetal sheep plasma are regulated by glucose and insulin. Eur. J. Endocrinology 131, 398-404

Gambardella P., Sticchi R., Ferrante P., D’Aponte D., 1987. Hyper- and hypoproteic diet in growing rats: comparison between effects and evaluation of damages. Int. J. Vitam. Nutr. Res. 57, 441-445

Gardner D.S., Jackson A.A., Langley-Evans S.C., 1997. Maintenance of maternal diet-induced hypertension in the rat is dependent on glucocorticoids. Hypertension 30, 1525-1530

Gatford K.L., Boyce J.M., Blackmore K., Smits R.J., Campbell R.G., Owens P.C., 2004. Long-term, but not short-term, treatment with somatotropin during pregnancy in underfed pigs increases the body size of progeny at birth. J. Anim. Sci. 82, 93-101

Glickman J.A., Challis J.R., 1980. The changing response pattern of sheep fetal adrenal cells throughout the course of gestation. Endocrinology 106, 1371-1376

Gluckman P.D., Butler J.H., Comline R., Fowden A., 1987. The effects of pancreatomy on the plasma concentrations of insulin-like growth factors 1 and 2 in the sheep fetus. J. Develop. Physiol. 9, 79-88

Gluckman P.D., Mueller P.L., Kaplan S.L., Rudolph A.M., Grumbach M.M., 1979. Hormone ontogeny in the ovine fetus. I. Circulating growth hormone in mid and late gestation. Endocrinology 104, $162-168$

Godfrey K.M., Barker D.J., 2000. Fetal nutrition and adult disease. Amer. J. Clin. Nutr. 71, Suppl. 5, $1344 \mathrm{~S}-1352 \mathrm{~S}$

Hales C.N., Barker D.J., 1992. Type 2 (non-insulin-dependent) diabetes mellitus: the thrifty phenotype hypothesis. Diabetologia 35, 595-601

Harding J.E., Liu L., Evans P.C., Gluckman P.D., 1994. Insulin-like growth factor 1 alters feto-placental protein and carbohydrate metabolism in fetal sheep. Endocrinology 134, 1509-1514

Hofman P.L., Cutfield W.S., Robinson E.M.M., Bergman R.N., Menon R.K., Sperling M.A., Gluckman P.D., 1997. Insulin resistance in short children with intrauterine growth retardation. J. Clin. Endocrinol. Metab. 82, 402-406

Jaquet D., Gaboriau A., Czernichow P., Levy-Marchal C., 2000. Insulin resistance early in adulthood in subjects born with intrauterine growth retardation. J. Clin. Endocrinol. Metab. 85, 1401-1406

Jones A.P., Pothos E.N., Rada P., Olster D.H., Hoebel B.G., 1995. Maternal hormonal manipulations in rats cause obesity and increase medial hypothalamic norepinephrine release in male offspring. Develop. Brain Res. 88, 127-131

Kattesh H.G., Baumbach G.A., Gillespie B.B., Schneider J.F., Murai J.T., 1997. Distribution between protein-bound and free forms of plasma cortisol in the gilt and fetal pig near term. Biol. Neonate 72, 192-200

Klemcke H.G., Sampath Kumar R., Yang K., Vallet J.L., Christenson R.K., 2003. 11ß-hydroxysteroid dehydrogenase and glucocorticoid receptor messenger RNA expression in porcine placentae: effects of stage of gestation, breed, and uterine environment. Biol. Reprod. 69, 1945-1950

Kuhn G., Rehfeldt C., Stabenow B., Nürnberg G., Ender K., 2003. Birth weight affects postnatal growth, body composition, and meat quality in pigs. Arch. Anim. Breed. 46, 171-175

Kwong W.Y., Wild A.E., Roberts P., Willis A.C., Fleming T.P., 2000. Maternal undernutrition during preimplantation period of rat development causes blastocyst abnormalities and programming of postnatal hypertension. Development 127, 4195-4202

Langley S.C., Jackson A.A., 1994. Increased systolic blood pressure in adult rats induced by fetal exposure to maternal low protein diets. Clin. Sci. 86, 217-222, discussion 121

Langley S.C., Seakins M., Grimble R.F., Jackson A.A., 1994. The acute phase response of adult rats is altered by in utero exposure to maternal low protein diets. J. Nutr. 124, 1588-1596 
Langley-Evans S.C., 1997. Hypertension induced by fetal exposure to maternal low protein diet in the rat is prevented by pharmacological blockade of glucocorticoid synthesis. J. Hypertension 15, 537-544

Law C.M., Shiell A.W., 1996. Is blood pressure inversely related to birth weight? The strength of evidence from a systematic review of the literature. J. Hypertension 14, 935-941

Lesage J., Blondeau B., Grino M., Bréant Dupouy J.P., 2001. Maternal undernutrition during late gestation induses fetal overexposure to glucocorticoids and intrauterine growth retardation, and disturbs the hypothalamo-pituitary adrenal axis in the newborn rat. Endocrinology 142, 16921702

Li J., Forhead A.J., Dauncey M.J., Gilmour R.S., Fowden A.L., 2002. Control of growth hormone receptor and insulin-like growth factor-I expression by cortisol in ovine fetal skeletal muscle. J. Physiol. 541.2, 581-589

Li J., Saunders J.C., Gilmour R.S., Silver M., Fowden A.L., 1993. Insulin-like growth factor-II messenger ribonucleic acid expression in fetal tissue of sheep during late gestation: effects of cortisol. Endocrinology 132, 2083-2089

Liu J.P., Baker J., Perkins A.S., Robertson E.J., Efstratiadis A., 1993. Mice carrying null mutations of the genes encoding insulin-like growth factor 1 (igf-1) and the type 1 IGF receptor (igflr). Cell $75,59-72$

Lopez M.F., Dikkes P., Zurakowski D., Villa-Komaroff L., Majzoub J.A., 1999. Regulation of hepatic glycogen in the insulin-like growth factor II-deficient mouse. Endocrinology 140, 1442-1448

Mahan D.C., Mangan L.T., 1975. Evaluation of various protein sequences on the nutritional carry-over from gestation to lactation with first-litter sows. J. Nutr. 105, 1291-1298

Mathews L.S., Hammer R.E., Behringer R.R., D’Ercole A.J., Bell G.I., Brinster R.L., Palmiter R. D., 1988. Growth enhancement of transgenic mice expressing human insulin-like growth factor-I. Endocrinology 123, 2827-2833

Menon R.K., Sperling M.D., 1996. Insulin as growth factor. Endocrinol. Metab. Clin. N. Amer. 25, 633-647

Metges C.C., 2001. Does dietary protein in early life affect the development of adiposity in mammals? J. Nutr. 131, 2062-2066

Meyer J.S., 1985. Biochemical effects of corticosteroids on neural tissues. Physiol. Rev. 65, 946-1021

Mi J., Law C., Zhang K.L., Osmond C., Stein C., Barker D., 2000. Effects of infant birthweight and maternal body mass index in pregnancy on components of the insulin resistance syndrome in China. Ann. Intern. Med. 132, 253-260

Muaka S.M., Thissen J.P., Gerard G., Ketelslegers J.M., Maiter D., 1997. Postnatal catch-up growth induced by growth hormone and insulin-like growth factor-I in rats with intrauterine growth retardation caused by maternal protein malnutrition. Pediat. Res. 42, 370-377

Oliver M.H., Harding J.E., Breier B.H., Evans P.C., Gluckman P.D., 1993. Glucose but not a mixed amino acid infusion regulates plasma insulin-like growth factor-I concentrations in fetal sheep. Pediat. Res. 34, 62-65

Oliver M.H., Hawkins P., Harding J.E., 2005. Periconceptional undernutrition alters growth trajectory and metabolic and endocrine responses to fasting in late-gestation fetal sheep. Pediat. Res. 57, 591-598

Ozanne S.E., Dorling M.W., Wang C.L., Nave B.T., 2001. Impaired PI 3-kinase activation in adipocytes from early growth-restricted male rats. Amer. J. Physiol.-Endocrinol. Met. 280, E534-E539

Ozanne S.E., Hales C.N., 2004. Lifespan: catch-up growth and obesity in male mice. Nature 427, 411-412

Ozanne S.E., Lewis R., Jennings B.J., Hales C.N., 2004. Early programming of weight gain in mice prevents the induction of obesity by a highly palatable diet. Clin. Sci. 106, 141-145 
Ozanne S.E., Smith G.D., Tikerpae J., Hales C.N., 1996. Altered regulation of hepatic glucose output in the male offspring of protein-malnourished rat dams. Amer. J. Physiol. Pt. 1, 270, E559-E564

Petrie L., Duthie S.J., Rees W.D., McConnell J.M.L., 2002. Serum concentrations of homocysteine are elevated durino early pregnancy in rodent models of fetal programming. Brit. J. Nutr. 88, 471-477

Rees W.D., Hay S.M., Buchan V., Antipatis C., Palmer R.M., 1999. The effects of maternal protein restriction on the growth of the rat fetus and its amino acid supply. Brit. J. Nutr. 81, 243-250

Rivero F., Goya L., Alaez C., Pascuel-Leone A.M., 1995. Effects of undernutrition and diabetes on serum and liver mRNA expression of IGFs and their binding proteins during rat development. J. Endocrinol. 145, 427-440

Schneider H., 1996. Ontogenic changes in the nutritive function of the placenta. Placenta 17, 15-26

Sloan N.L., Lederman S.A., Leighton J., Himes J.H., Rush D., 2001. The effect of prenatal dietary protein intake on birth weight. Nutr. Res. 21, 129-139

Thomas L., Wallace J.M., Aitken R.P., Mercer J.G., Trayhurn P., Hoggard N., 2001. Circulating leptin during ovine pregnancy in relation to maternal nutrition, body composition and pregnancy outcome. J. Endocrinol. 169, 465-476

Thongsong B., Bonkobara M., Matsumoto M., Jang J.-S., Matsuli N., Inaba M., Ono K., 2002. Effects of insulin-like growth factor-I on maternal and fetal plasma amino acid levels in pregnant rats. J. Vet. Med. Sci. 64, 859-861

Vickers M.H., Breier B.H., Cutfield W.S., Hofman P.L., Gluckman P., 2000. Fetal origins of hyperpagia, obesity and hypertension and postnatal amplification by hypercaloric nutrition. Amer. J. Physiol. - Endocrinol. Met. 279, E83-E87

Vickers M.H., Breier B.H., McCarthy D., Gluckman P.D., 2003. Sedentary behavior during postnatal life is determined by the prenatal environemt and exacerbated by postnatal hypercaloric nutrition. Amer. J. Physiol. - Regul. Integr. C. 285, R271-R273

Vickers M.H., Ikenasio B.A., Breier B.H., 2001. IGF-I treatment reduces hyperphagia, obesity, and hypertension in metabolic disorders induced by fetal programming. Endocrinology 142, 39643973

Wallace J.M., Aitken R.P., Milne J.S., Hay W.W., 2004. Nutritionally mediated placental growth restriction in the growing adolescent: consequences for the fetus. Biol. Reprod. 71, 1055-1062

Wallace J.M., Bourke D., Aitken R.P., Milne J.S., Hay W.W., 2002. Placental glucose transport in growth-restricted pregnancies induced by overnourishing adolescent sheep. J. Physiol. 547.1, 85-94

Wallace J.M., Bourke D.A., Da Silva P., Aitken R.P., 2003. Influence of progesterone supplementation during the first third of pregnancy on fetal and placental growth in overnourished adolescent ewes. Reproduction 126, 481-487

Wallace J.M., Da Silva P., Aitken R.P., Cruickshank M.A., 1997. Maternal endocrine status in relation to pregenancy outcome in rapidly growing adolescent sheep. J. Endocrinol. 155, 359-368

Whorwood C.B., Firth K.M., Budge H., Symonds M.E., 2001. Maternal undernutrition during early to midgestation programs tissue-specific alterations in the expression of glucocorticoid receptor, 11ß-hydroxysteroid dehydrogenase isoforms, and type 1 angiotensin II receptor in neonatal sheep. Endocrinology 142, 1778-1785

Wise T., Stone R.T., Vernon M.W., 1991. Relationships of serum estradiol, cortisol and albumin concentrations with pig weight at 110 days of gestation and at birth. Biol. Neonate 59, 114-119

Yuen B.S.J., Owens P.C., McFarlane J.R., Symonds M.E., Edwards L.J., Kauter K.G., McMillen I.C., 2002. Circulating leptin concentrations are positively related to leptin messenger RNA expression in the adipose tissue of fetal sheep in the pregnant ewe fed at or below maintenance energy requirements during late gestation. Biol. Reprod. 67, 911-916 


\section{STRESZCZENIE}

\section{Programowanie żywienia: wpływ żywienia prenatalnego na regulację wzrostu i metabolizmu}

Badania nad żywieniem płodowym gryzoni, jako czynnikiem wywołującym choroby u osobników dorosłych, doprowadziły do odkrycia wielu czynników programowania, wpływających na metabolizm i układ sercowo-naczyniowy. Zależność ta jest konsekwencją zaburzeń wzrostu płodu oraz zmian w zaprogramowanym rozwoju różnych punktów kontrolnych regulujących homeostazę. Do niedawna mało uwagi poświęcano zastosowaniu wczesnego programowania żywienia zwierząt domowych. W referacie przedstawiono przykłady wpływu programowania rozwoju płodowego, przy niedożywieniu lub nadmiernym żywieniu ogólnym i białkowym, u gryzoni i owiec. Omówiono zmiany w matecznym i płodowym układzie endokrynnym, obejmującym glukokortykoidy, insulinę i insulino-podobny czynnik wzrostu, powiązane z nieodpowiednim żywieniem matki podczas ciąży. 